\title{
Chapter 14 \\ Commentary: Flood Retention in Urban Floodplains-A Plzen Case Study \\ from the Viewpoint of a Hydraulic \\ Engineer
}

\author{
Reinhard Pohl
}

\section{Introduction}

Since ancient times, people have been settling near rivers that were used for water supply, irrigation, wastewater disposal and. in the case of larger rivers, as a navigable waterway, as a border or line of defense. On the one hand, the suspended matters of the rivers fertilized the temporarily inundated land during floods, and, on the other hand, floods could endanger the people living in the flood-prone area. Thus, the two main issues of hydraulic engineering (building structures for the use of water and protection against the water) remain an everlasting challenge.

As natural rivers are wide, meandering and not very deep, they were often accompanied by large wetlands and bends that were able to store water during floods. Inundations of these areas were a normal process without hazards and damages because these can only occur in a man-made environment. Later the river-near land was needed and used for settlement and economic activities so that an inundation could cause damages and the area had to be flood-protected. Reducing the inundation area could cause a reduction of the retention effect so that floods with less reduced peaks were able to pass.

\section{The Lobezská Louka Site}

The rivers Úhlava, Úslava $(65.7 \mathrm{~km})$, Radbuza, and Mže have their confluence in or near Plzen (Pilsen) to form the river Berounka, which is a left tributary of the Vltava (Moldau) with the junction upstream of the city of Prague. The Lobezská Louka (meadow) area at the Úslava river in the city of Plzen was an unmanaged green

R. Pohl $(\varangle)$

TU Dresden/Institut für Wasserbau und Technische Hydromechanik, Dresden, Germany

e-mail: Reinhard.Pohl@TU-Dresden.de

T. Hartmann et al. (eds.), Nature-Based Flood Risk Management on Private Land, 
overgrown with wild tree seedlings and with occasional illegal dumps. The area of the original wetlands was split into lots with several owners, who were following different interests with their estates.

In the addressed chapter, the authors Macháč and Louda report on this area in Plzen that was given back to the Úslava river. By doing so, wetlands with a nature-near state were restored to improve the possibilities for recreation, biological diversity and flood protection.

\section{Hydraulic Aspects of Wetland Retention}

In order to understand flood routing and protection, one must know that the flow in every river or channel is subjected to a small peak reduction, which is caused by the different hydraulic gradients of the coming and leaving flood wave (Bornschein and Pohl 2017). This brings a higher propagation celerity of the flood wavefront and a slower velocity on the reverse side of the wave. If a considerable cut of the peak is desired or needed, large storage volumes are required that should be gated additionally so that the storage is not filled before the arrival of the flood peak.

In the presented case, this means that the estimated mean flow of $1.5 \mathrm{~m}^{3} / \mathrm{s}$ can be stored for 1-2 $\mathrm{h}$ assuming a storage of $8000 \mathrm{~m}^{3}$. A 100-year-flood with a peak of more than $200 \mathrm{~m}^{3} / \mathrm{s}$ will not be retarded or reduced by the recreated wetlands because the flood wave volume of some million cubic meters will fill the storage area completely within only a few minutes, long before the peak arrives. The above numbers are only estimations because they were not given in the original paper and not available from the online catchment basin information (rivers.raft.cz/cechy/ uslava.aspx). Considering the relative large catchment area of more than $90 \mathrm{~km}^{2}$, they might be still underestimated.

Figure 14.1 shows example hydrographs of a small flood (say 2-yr flood) and a large flood (say 100-yr flood) in comparison. All areas in the chart indicate water volumes because the vertical diagram axis represents the discharge and the horizontal axis depicts the time. It is visible that, for the small event, a peak reduction is possible, whereas, for the large event, a controlled storage is required. Only when its inlet gates are opened at point $\mathrm{P}$ the expected peak reduction can be reached.

Often it is postulated that a couple of small protection measures are better than one large measure. As the economic and hydraulic efficiency depends on many influences, it cannot be said without profound analysis of each particular case whether one large or several smaller flood protection measures will bring the better effect. However, it can be said that every measure to revitalize an industrial wasteland or not used urban "grey" area will be a facelift for the city as well as a step towards a nature-near river situation.

In this analysis, many input values have to be estimated or adopted from other case studies. From this fact, a considerable uncertainty of the results arises. Another issue is the comparison of values with different dimensions because not all relevant quantities or qualitative properties can be converted to monetary values that can be 


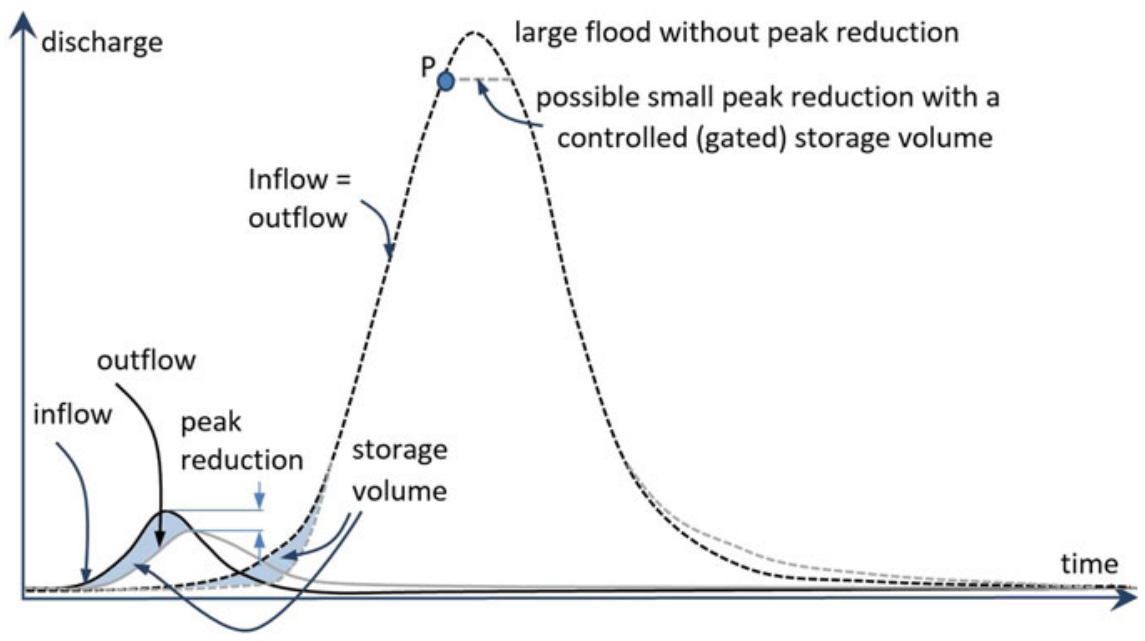

Fig. 14.1 Effect of a small nature-based flood protection measure. Comparison of a small flood (solid lines) and a large flood (dotted lines). Inflow hydrograph: black line, outflow: grey lines. Hatched area: storage volume

expressed in terms of a currency. In such cases, a Pareto optimization may help to indicate improving items without worsening of other items.

When speaking about NBS or non-structural methods, we must also consider that these projects need a lot of construction work, at least during the phase of project implementation, but in many cases also during its lifetime. Insofar these measures are structural measures including earthwork, excavation, reinforcement of embankments, building pathways and roads and in some cases also bridges, inlet/outlet structures, and flood defences.

\section{Conclusion}

Small measures can only affect small floods. Nevertheless, they can help to reduce the frequency of inundations downstream. In the present case with a retention storage capacity of about $8000 \mathrm{~m}^{3}$, only protection against very frequent events might be expected. When calculating costs and benefits, the main benefit in the Lobezská Louka (meadow) area might not arise from the flood protection but from other effects like restoration of the floodplain area, removal of illegal rubbish dumps, establishing a recreation area for inhabitants, etc. (Dittmann et al. 2009).

The example of the Lobezka Louka demonstrates that it is possible to recreate an urban area to become a wetland close to the assumed original situation before the urban development. At this juncture, the cooperation of all stakeholders, including 
the landowners, is essential. This will allow land recycling instead of additional land consumption.

Acknowledgements Open access of this chapter is funded by COST Action No. CA16209 Natural flood retention on private land, LAND4FLOOD (www.land4flood.eu), supported by COST (European Cooperation in Science and Technology).

\section{References}

Bornschein A, Pohl R (2017) Land use influence on flood routing and retention from the viewpoint of hydromechanics. J Flood Risk Manag 403(2011):103. https://doi.org/10.1111/jfr3.12289

Dittmann R, Froehlich F, Pohl R, Ostrowski M (2009) Optimum multi-objective reservoir operation with emphasis on flood control and ecology. Nat Hazards Earth Syst Sci NHESS 9(6):1973-1980

Reinhard Pohl studied Hydraulic Engineering and got his Ph.D. from the Dresden University of Technology. After four years with Hydroprojekt Consultants, he came back to the University in 1993. His working fields are hydromechanics, flood protection, dams, weirs, levees and the safety of hydraulic structures. After receiving the venia legendi in 1998, he became a Professor of hydromechanics in civil engineering in 2002. He is author or co-author of several textbooks, German DIN standards and guidelines on dams and levees and many scientific papers.

Open Access This chapter is licensed under the terms of the Creative Commons Attribution 4.0 International License (http://creativecommons.org/licenses/by/4.0/), which permits use, sharing, adaptation, distribution and reproduction in any medium or format, as long as you give appropriate credit to the original author(s) and the source, provide a link to the Creative Commons license and indicate if changes were made.

The images or other third party material in this chapter are included in the chapter's Creative Commons license, unless indicated otherwise in a credit line to the material. If material is not included in the chapter's Creative Commons license and your intended use is not permitted by statutory regulation or exceeds the permitted use, you will need to obtain permission directly from the copyright holder.

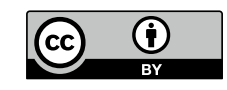

